\title{
Impact of Foreign Direct Investment (FDI) on Economic Growth in WAEMU from 1990 to 2012
}

\author{
Galaye Ndiaye ${ }^{1} \&$ Helian $\mathrm{Xu}^{1}$ \\ ${ }^{1}$ College of Economics and International Trade, Hunan University, Changsha, China \\ Correspondence: Galaye Ndiaye, College of Economics and International Trade, Hunan University, Changsha, Hunan, \\ China.
}

Received: April 11, 2016

Accepted: May 4, 2016

Online Published: June 25, 2016

doi:10.5430/ijfr.v7n4p33

URL: http://dx.doi.org/10.5430/ijfr.v7n4p33

\begin{abstract}
In recent years, the effect of Foreign Direct Investment (FDI) on economic growth has been increasing, in developing countries, particularly in Africa. In their attempt to attract FDI, most African countries such as WAEMU (West African Economy Monetary Union) countries have liberalized trade and attempted to create an enabling environment. The purpose of our study is to investigate the impact of FDI on economic growth for WAEMU countries. We developed a theoretical model of investment that included an FDI variable and tested it with panel data from 1990 to 2012 . The model is run for seven (7) developing countries in Africa. The estimation results show that FDI has a positive impact on economic growth. We found that FDI in WAEMU is going to facilitate the trade, FDI liberalization, economic cooperation, improve the business environment and increase the labour cost. FDI will allow WAEMU countries to attract more foreign capital for the creation of jobs and wealth. Based upon these results, the ultimate objective of our paper concludes that the Impact of FDI on economic growth is beneficial for host country's trade and investment. The increasing of investment in WAEMU countries could generate important gains for most of African economies.
\end{abstract}

Keywords: GDP, foreign direct investment, economic growth, capital, WAEMU

\section{Introduction}

In the 1950s and 1960s many developing countries considered foreign direct investment (FDI) and multinational national enterprises (MNEs) to be a menace to national sovereignty and detrimental to the economic development. FDI was seen as a dominating factor in development to reduce social welfare by manipulating transfers, prices and the formation of enclaves. At the exit of the colonial period, the economic situation of most African countries was basically characterized as low levels of economic, social and cultural development. Communication infrastructures were practically nonexistent, health coverage and education levels were very low. Thus from their accession to independence, most of WAEMU countries embarked on a process of economic, social and cultural achievements. They invested in public infrastructure, agriculture, industry and services often with capital borrowed from outside.

Over the last couple of decades, the attitude towards inward foreign direct investment has changed considerably, as most Africans countries have liberalized their foreign policies to attract investments from foreign multinational corporations. They are witnessing a radical change in the attitude of developing countries opposition to FDI. It's now considered an important tool for economic development. This change in attitude toward FDI can be explained by many factors such as: the worldwide context of economic liberalisation and the pressure on less developed countries (LDCs) to resolve their economic problems like unemployment, lack of domestic investment and the need to have modern technologies. FDI also supports the transfer of production technology from developed to developing countries. It would contribute more to economic growth than domestic private investment.

Developing countries such as WAEMU countries today are aware of the potential gains that foreign direct investors can make to their economies. These countries want to expand the price mechanism as a factor in resolving imbalances in the private sector by attracting more foreign direct investment to solve the problem of excessive debt they face. From a theoretical point of view, when a country faces a shortfall in resources internally, it will also face a deficit that could be filled by an influx of foreign capital. In macroeconomic terms, this means that when government spending and private investment exceeds domestic investment, respectively, the state revenues and domestic savings, results in a deficit that leads to internal imports above exports; then foreign financial institutions are asked to fill the gap created. 
The absorption of the latter can be done by the domestic and external financing, but also through foreign direct investment.

Like many other developing countries, WAEMU Countries have made the remarkable transformation from being hostile to foreign direct investment to attracting multinational firms. Moreover, given the level achieved in the implementation of various projects of integration of the WAEMU combined benefits in the existing monetary and financial matters, it was sufficiently indicated that the motivations for FDI are stronger in this area. The geographical proximity and cheap labour cost of WAEMU countries are some of the few advantages that contribute towards attracting more investors. This paper is organized as follows: the first section provides the literature review; section 2 introduces the trends of FDI in WAEMU, the third section is deals with the methodology as well as describing the data used in the research, the fourth section discusses about the empirical results and finally, the last section concludes the paper.

\section{Literature Review}

There has been very little literature on the impact of Foreign Direct Investment on economic growth of WAEMU. Most authors have concentrated more on literature on the impact on foreign direct investment in developing countries.

According to our research, we can say, a large number of studies have analyzed the relationship between FDI and economic growth in Africa. The main research concern is whether FDI has an impact on a country's economic development and to what extent. The implicit assumption made is that economic growth naturally leads to welfare improvement. Recently, some authors have questioned the role a country's financial market development plays on this linkage. Overall, the answers to these concerns are mixed, even though the tendency is towards the positive impact of FDI inflows on economic growth in Africa. These contradictory answers may be due to a number of methodological and conceptual factors, including the lack of a comprehensive harmonized datasets, variation of various definitions of FDI, and different econometric specifications. Most authors indicate that when it comes to Foreign Direct Investment in Africa, what comes to mind is investment in natural resources, mainly investment in minerals and oils. This assumption means that FDI is basically determined by an uncontrollable factor and that poor countries with deficiency of natural resources, like WAEMU countries, will attract very little or no FDI regardless of the policies that the country pursues.

Our research attempts to overcome this limitation. It emphasizes on identifying clearly what needs to be done at the national, regional, and international level in order to enhance FDI flows in WAEMU.

Ogiogio (1995) reports negative contributions of public investment to GDP growth in Africa for reasons of distortions. Endozien (1968) discusses the linkage effects of FDI in African economy and submits that these have not been considerable and that the broad linkage effects were lower than the Chenery-Watanabe average (Chenery and Watanabe, 1958). Oseghale and Amonkhienan (1987) found that FDI is positively associated with GDP, concluding that greater inflow of FDI will spell a better economic performance for developing countries.

Ariyo (1998) studied the investment trend and its impact in African economic growth over the years. He found that only private domestic investment consistently contributed to raising GDP growth rates during the period considered (1970-1995). Furthermore, there is no reliable evidence that all the investment variables included in his analysis have any perceptible influence on economic growth. He therefore suggests the need for an institutional rearrangement that recognizes and protects the interest of major partners in the development of the economy.

Blomstrom et al. (1994) reported that FDI exerts a positive effect on economic growth, but that there seems to be a threshold level of income above which FDI has positive effect on economic growth and below which it does not. The explanation was that only those countries that have reached a certain income level can absorb new technologies and benefit from technology diffusion, and thus reap the extra advantages that FDI can offer. Previous works suggest human capital as one of the reasons for the differential response to FDI at different levels of income. This is because it takes a well-educated population to understand and spread the benefits of new innovations to the whole economy. Borensztein et al. (1998) also found that the interaction of FDI and human capital had important effect on economic growth, and suggest that the differences in the technological absorptive ability may explain the variation in growth effects of FDI across countries. They further suggested that, countries may need a minimum threshold stock of human capital in order to experience positive effects of FDI.

FDI is generally associated with Multinational Corporations (MNCs), which are enterprises owning or controlling value-adding activities in two or more countries. Several authors featured the FDI in a bid to imply gaining access to advanced technology and management skills, to increase the employment level, the competition in the domestic market and the tax revenue and/or to boost the economic growth. 
Dunning proposes in his article analytical framework $(1977,1993)$ considers explanatory factors of FDI imperfect competition, comparative advantage and the internationalization of transaction costs. This approach OLI paradigm (Ownership, Localization International) considers a number of advantages in growing multinational companies (MNC) to invest abroad. We argued above that technology spillovers provide externalities that should have a positive effect on economic growth in the host country. Besides knowledge-capital, FDI can also generate an inflow of physical and human capital to the host country. As the physical size of the host country capital stock increases, the productive capacity of the host country also increases.

Laura Alfaro (Harvard Business School, Morgan 263, and Boston) shows that foreign direct investment (FDI) can provide great benefits to host countries. The author found in his study that economic growth can be significantly affected by foreign direct investment since Solow type models rules out capital as a source of long-run per capita growth, in such a framework FDI can only affect growth through an inflow of capital in the short run while the economy is in transition toward steady state. Empirical research on the role of capital accumulation for economic growth has not been conclusive. Easterly and Levine (2001) used a growth accounting framework and reached the conclusion that investment in physical capital is relatively unimportant in explaining long run economic growth since technological progress accounts for most of the cross-country variation in growth. However, Bond et al (2004) argues that this conclusion is premature since the modelling framework in Easterly and Levine is too restrictive.

The article by Andrew Mold develops the issue of FDI effects on the poorest countries, in questioning specifically, on their contribution to poverty reduction, new targets set by the Bretton Woods institutions and which now refers a majority of donors. The author casts doubt on the positive nature of this relationship in regard to least developed countries (LDCs). The author considers that the efforts of governments of developing countries to attract multinational companies, particularly in special economic zones, are disproportionate to the relatively low share of jobs being offered by these firms (4 million in the free zones of developing countries against 1.2 billion people living below the poverty line of $\$ 1$ per day).

Mold, in his article from critics developed by Stiglitz ore, assess the arguments concerning the effects of FDI on poverty reduction. He notes that Stiglitz, without denying the role of foreign companies, more and more authors relatives the benefits of FDI to wait and recognize that many of them have abused their dominant position in the country poor.

By contrast, Blomstrom et al. (1992) find no support that human capital is important; however, they find that FDI promotes growth when the host economy is a developed one. Nair-Reichert and Weinhold (2001), however, claim that the results of such macro studies are flawed due to the homogeneity of assumptions across countries in studies on FDI-growth relationship. They find that the causal relationship between investment (foreign and domestic) and economic growth in developing countries is highly heterogeneous. According to Boyd and Smith (1992), FDI may slow growth by hampering resource allocation in the presence of pre-existing trade, price and other distortions. In a relatively recent work, Carkovic and Levine (2002) claim that previous macroeconomic studies do not fully control endogeneity, country-specific effects, and the inclusion of lagged dependent variables in the growth regression. They show that after controlling the statistical problems, their results are inconsistent with the view that FDI exerts a positive impact on growth that is independent of other growth determinants. The link between FDI and regional integration is also investigated in the literature. Darrat et al. (2005) examine the impact of FDI on growth in Central and Eastern Europe (CEE) and the Middle East and North Africa (MENA) regions finding that FDI affects growth positively only in the European Union accession countries of the CEE region.

Dr. Brahim Mansouri (United Nations Economic for Africa commission African Conference 2009) says that recent theoretical developments that argue that some explanatory variables falling should be introduced into the Standard Model of Economic Growth. This article focuses on the impact of FDI on economic growth and the benefits of FDI in Africa.

We therefore can say that, the empirical evidence for so many authors suggests that FDI plays an important role towards economic growth but the level of development of local financial markets is crucial for these positive effects to be realized. We see, using econometric specifications that allow FDI influence growth differently, depending on national income, trade openness, education and domestic financial development; they find that FDI does exert a robust and positive impact on economic growth.

Several other authors found similar results using different databases and methodologies. A good example is Alfaro and Charlton (2007), who distinguish different "qualities" of FDI to re-examine the relationship between FDI and growth. In their study, 'quality' means an effect a unit of FDI has on economic growth. Exploiting a new comprehensive industry level data set of 29 countries between 1985 and 2005, they find that the growth effects of FDI increase when 
they account for the quality of FDI. After controlling the industry characteristics and time effects, they find the relation between FDI and economic growth was no longer ambiguous but rather positive and significant.

We can say some results show that FDI Granger-causes economic growth, and vice-versa. However, the effects are rather more apparent from growth to FDI than from FDI to growth. We review some literature but we can conclude that FDI may affect not only the level of output per capital but also its rate of growth and Human capital augmentation increase export. So FDI is the most important but others variables too contribute to growth depending on the economic growth.

\section{Trends of FDI in WAEMU Countries}

We note that the curve of FDI in WAEMU countries from 1990 to 2012 is rising. This indicates an increasing trend of FDI inflow to these countries although in some countries there has been a constant trend for some years. Niger is one of the WAEMU countries which received the most FDI inflow indicating a rising trend in foreign investment from 2008 to 2012. Then there's Mali following Niger from 2004 to 2010 with a value that increases to US $\$ 1,900,000$ to US $\$ 80,000,000$. Ivory Coast, Burkina Faso and Senegal come in third place because we see Ivory Coast was shaken in recent years by several wars that cause the country to lose many of these FDI flows. In 1992, it recorded the most negative value in this area $-2 \mathrm{E}+08$. From 1990 to 1992, Benin shows a stable trend; its curve is constant until the year 2005 where it starts to gain a slight increase in FDI. And finally in this Union Togo receives the least of FDI because it is part of the poorest countries in the WAEMU zone given that it doesn't have many resources to attract more investors.

We see some recent trends in WAEMU countries: since 2000, private capital inflows (FDI, portfolio investment, etc.) have increased steadily in the WAEMU. This trend has however come to a halt in 2005 but sees a resurgence of FDI in 2012.

\section{Evolution of FDI in WAEMU countries}

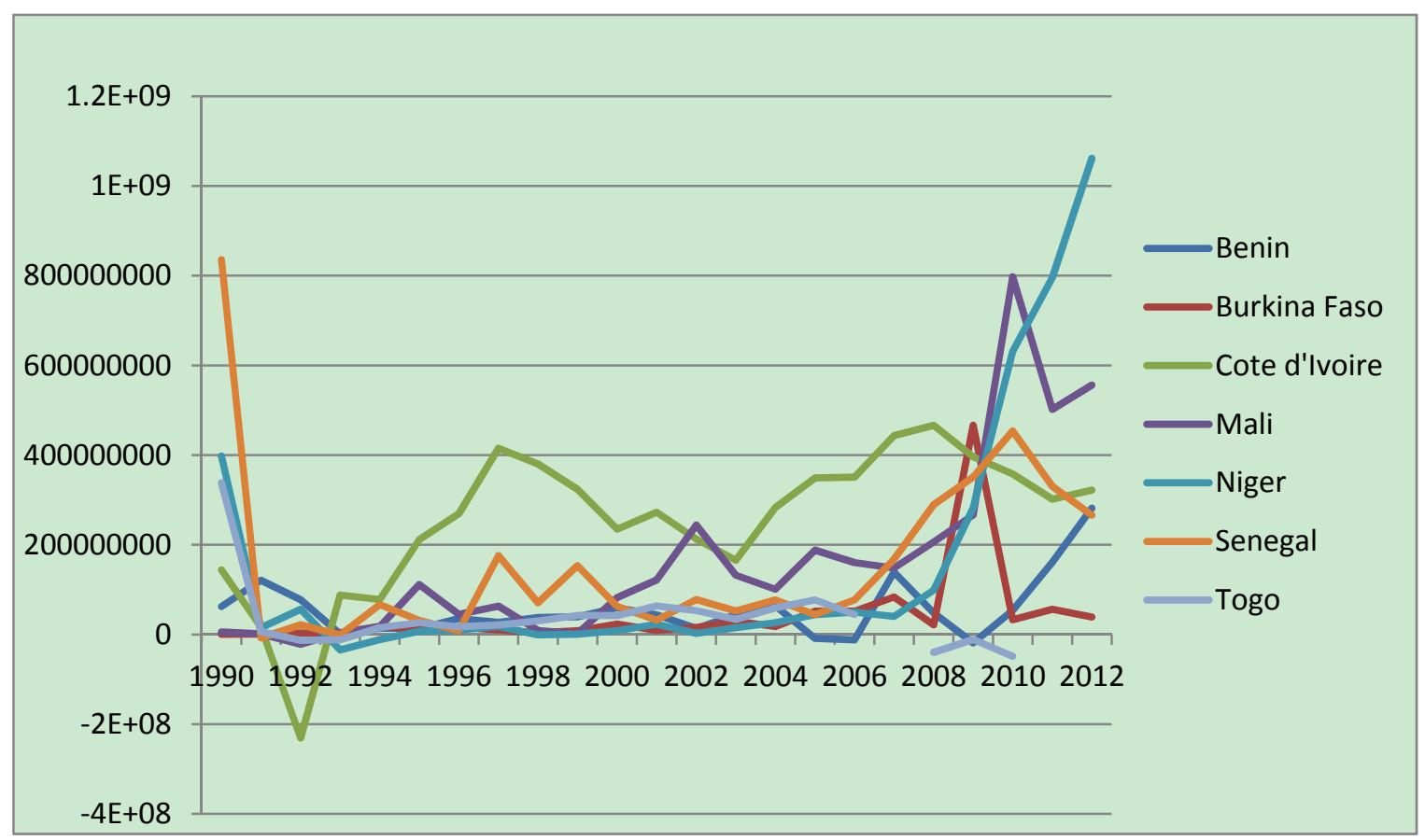

\section{Methodology}

Panel estimation has been employed to analyze of the model. This has been done in order to allow for a large number of degrees of freedom. Large numbers of degrees for freedom are important when a model uses several explanatory variables to characterize the multiple determinants of FDI inflow.

$$
\mathrm{Y}=\mathrm{f}(\mathrm{A}, \mathrm{FDI}, \mathrm{K})
$$

Where $\mathrm{Y}$ is the output, $\mathrm{K}$ is capital and $\mathrm{L}$ is labour and $\mathrm{A}$ is the technology or the efficiency of production. 
Our model is based on the assumption that FDI contributes to economic growth directly through new technologies and other inputs as well as indirectly through improving government, and institutions and the level of a country's productivity depends on FDI, trade and domestic investment. As a variable, GDP captures the total factor productivity (TFP) effect on growth in output and it is assumed that the effect of FDI on growth operates through variable GDP, and the effect of FDI on economic growth also depends on the Trade, Labour, Government and Domestic Investment.

Our econometric model is derived from a production function in which the level of a country's productivity depends on FDI, trade, domestic investment, capital, inflation, government, labour, domestic investment and initial gross domestic product (GDP) per capita. The model is based on endogenous growth theory, this section develops the estimating equation and draws from literature by using the augmented production function approach in investigating of impact of FDI on economic growth in WAEMU during the period 1980- 2005.

To assess empirically the impact of FDI on economic growth in WAEMU, we specify the following basic formulation:

$$
\log \mathrm{GDP}_{\mathrm{t}}=\beta_{0}+\beta_{1} \mathrm{FDI}+\beta_{2} \mathrm{GFCF}+\beta_{3} \mathrm{~K}+\beta_{4} \mathrm{INF}+\beta_{5} \mathrm{Gov}-\operatorname{cons}+\beta_{6} \mathrm{Lab}+\beta_{7} \mathrm{Trad}+\beta_{8} \mathrm{GR}+\epsilon_{\mathrm{it}}
$$

Where:

GDP $=$ per capital Gross domestic product

FDI $=$ per capita Foreign Direct Investment

$\mathrm{GFCF}=$ Gross fixe capital formation

$\mathrm{K}=$ Capital

$\mathrm{INF}=$ Inflation Rate

GOV $=$ Government Consumption

$\mathrm{Lab}=$ Labor

TRA $=$ Trade is the (export plus import) of goods and services

$\mathrm{GR}=$ Growth rate

$\varepsilon^{0}=$ Stochastic error term

The variables FDI, GFCF, TRA, K, GOV, Labor and Domestic-Investment are measured as ratios to GDP. Our model extends the work of Borensztein, Gregorio, and Lee to include the decade of the (1990s) when FDI and trade grew rapidly in the developing countries. We also account for interaction of FDI with trade and domestic investment.

The data for our analysis are obtained from the World Development Indicators (WDI) database. The WDI database, published by the World Bank and International Monetary Fund, includes variables such as GDP, per-capita income, FDI; trade in goods and services, domestic capital investment, trade openness, inflation rate, and government consumption. WAEMU countries are 8 countries but the data cover 7 countries for the years 1990 through 2012 because the data of Guinea-Bissau is unavailable and the data for the recent years are not available too.

\subsection{Hypothesis}

The hypothesis is that, FDI in WAEMU countries and related subjects impact on economic growth. The impact of structure of FDI by economic activity and GDP by economic activity was highlighted. The study seeks to verify the following hypotheses:

Hypothesis 1: $\frac{\text { FDI }}{\text { GDP }}>0$, foreign direct investment has a positive effect on Gross Domestic Product in WAEMU; this study expects that FDI inflows should have a positive effect on GDP. If there is an increase in FDI, this will contribute to the economic growth in WAEMU. In contrast, if the FDI is negative correlation to economic growth, it will not help GDP growth in a country.

Hypothesis 2: $\frac{\text { FDI }}{\text { Trade }}>0$, foreign direct investment has a positive effect on trade. Trade leads to specialization and expanding potential markets which allows domestic firms to take advantage of economies of scale, more competitive. This study expects Trade to have a positive effect on FDI as the openness to international market affects the probability of foreign investors. 
Hypothesis 3: $\frac{\text { FDI }}{\mathrm{INF}}<0$, FDI has an effect on inflation. High inflation is an indication of economic instability and it destroys the value of money. Value destruction implies a negative impact on economic growth and it can be inferred that the impact on FDI is negative

Hypothesis 4: $\frac{\text { FDI }}{\text { DOM INV }}>0$, FDI has a positive effect on domestic investment. High capital domestic investment leads to greater economic growth or shows the potential of the country for spending and thus has a significant impact on FDI. If there is an increase in capital there will affect in increase in domestic investment.

\section{Empirical Results}

This study estimates the effect of FDI on economic growth of WAEMU countries. Table 1 presents the summary of descriptive statistics using data averaged over 1990-2012. The summary statistics are calculated using one observation per country. There are considerable cross-country variations in the data.

Table 1. Summary of descriptive statistics

\begin{tabular}{llllll}
\hline Variable & Obs & Mean & Std. Dev & Min & Max \\
\hline GDP & 161 & 510.5511 & 276.7308 & 63.6401 & 1365.874 \\
\hline FDI & 158 & $1.25 \mathrm{e}+08$ & $1.87 \mathrm{e}+08$ & $-2.31 \mathrm{e}+08$ & $1.06 \mathrm{e}+09$ \\
\hline GFCF & 160 & $1.06 \mathrm{e}+09$ & $8.64 \mathrm{e}+08$ & $1.09 \mathrm{e}+08$ & $3.73 \mathrm{e}+09$ \\
\hline K & 160 & $1.07 \mathrm{e}+09$ & $9.33 \mathrm{e}+08$ & $9.22 \mathrm{e}+07$ & $4.46 \mathrm{e}+09$ \\
\hline Inflation & 161 & 4.461509 & 7.317451 & -9.823833 & 46.38607 \\
\hline Gov-cons & 159 & $7.75+08$ & $5.75 \mathrm{e}+08$ & $1.24 \mathrm{e}+08$ & $2.35 \mathrm{e}+09$ \\
\hline Labor & 161 & 4221989 & 1523875 & 1535335 & 7813057 \\
\hline Trade-open & 158 & $2.54 \mathrm{e}+09$ & $3.29 \mathrm{e}+09$ & 3038279 & $1.55 \mathrm{e}+10$ \\
\hline Growth & 161 & 3.612823 & 3.829718 & -15.09583 & 14.98241 \\
\hline
\end{tabular}

Table1 presents summary statistics for all variables used in this study and the data averaged over the 1990 to 2012 period, with one observation per country. For instance the mean of GDP for the sample is 510.5511 per annum, with a standard deviation of $1.87 \mathrm{e}+08$ it varies significantly, ranging from 63.6401 to 1365.874 in the sample.

FDI has a minimum of $-2.31 \mathrm{e}+08$ and a maximum of $1.06 \mathrm{e}+09$. The average is $1.25 \mathrm{e}+08$ and the standard deviation is $1.87 \mathrm{e}+08$, which is large, meaning it exhibit more dispersion from the mean. FDI can

The capital has a minimum value $9.22 \mathrm{e}+07$ and a maximum of $4.46 \mathrm{e}+09$. It has an average of $9.22 \mathrm{e}+07$ and the standard deviation is $9.33 \mathrm{e}+08$ which exceed the mean, hence it exhibit dispersion from the mean.

The lowest value of trade-openness is (3038279) and the highest value is $(1.55 \mathrm{e}+10)$. The average is $2.54 \mathrm{e}+09$ and the standard deviation $3.29 \mathrm{e}+09$ is large meaning, it exhibits more dispersion from the mean. According to trade of goods and services, we can say our expectation for our result should be a positive sign on economic growth.

Inflation has a minimum of -9.823833 and a maximum of 46.38607 . The average is 4.461509 and the standard deviation is 7.317451, which is large, meaning it exhibit more dispersion from the mean. Inflation, as expected, has a negative effect on attracting FDI but statistically less. As to the inflation, it may have dual information content; macroeconomic instability and high economic activity like the case of economic over-heating. Most African countries have not recorded sustainable economic growth let alone overheating, so it can be argued that the informational content of inflation leans more towards economic instability.

Labor has a minimum of 1535335 and the maximum is 7813057 . The mean is 4221989 , the standard deviation is 1523875 , meaning it exhibits less dispersion from the mean. We can say our expectation result for labor the sign is positive because the labor cost is cheap in African countries. Labor quantity, population growth rate, is found to have a positive but statistically insignificant effect using annual data. The labor quality is one of the significant factors, at $99 \%$ confidence interval, that determine FDI inflow. Poor countries have considerable discretion over how much to invest on education and training. The more an African country spends on human capital; it is found out that, the more FDI flows to that country. 
Government consumption is measured as the ratio of government consumption to GDP. It is expected to bear a direct relationship to economic growth. This is because a higher level of government consumption should translate into provision of more social capital that should encourage production and growth. The results of Government Consumption: have a minimum of $1.24 \mathrm{e}+08$; it means government consumption had increased by $5.16 \mathrm{e}+07$; while the maximum is $2.35 \mathrm{e}+09$. The mean of government consumption is $7.75+08$ and the standard deviation is $5.75 \mathrm{e}+08$ which is less than the average and means it exhibit less dispersion from the mean.

Finally, Growth rate has a minimum -15.09583 and a maximum 14.98241 . The mean is 3.612823 , the standard deviation is 3.8297185 , meaning it exhibits more dispersion from the mean

After the results of the descriptive statistics, we are allowed to know how we will follow our regressions.

The econometric result for the first regression model, where GDP is the dependent variable and others are independent variables is presented in Table 2.

Table 2. Simple regression

\begin{tabular}{cllllll}
\hline GDP & Coef & Std.err & $\mathbf{t}$ & \multicolumn{1}{c}{$\mathbf{P}>/ \mathbf{t} /$} & \multicolumn{1}{c}{$[\mathbf{9 5 \%} \boldsymbol{c}$ conf } & \multicolumn{1}{c}{ Interval] } \\
\hline FDI & $-1.84 \mathrm{e}-07$ & $5.37 \mathrm{e}-08$ & -3.42 & 0.001 & $-2.90 \mathrm{e}-07$ & $-7.74 \mathrm{e}-08$ \\
\hline GFCF & $2.61 \mathrm{e}-07$ & $4.31 \mathrm{e}-08$ & 6.06 & 0.000 & $1.76 \mathrm{e}-07$ & $3.47 \mathrm{e}-07$ \\
\hline K & $-6.86 \mathrm{e}-08$ & $3.78 \mathrm{e}-08$ & -1.81 & 0.072 & $-1.43 \mathrm{e}-07$ & $6.13 \mathrm{e}-09$ \\
\hline Inflation & -1.052038 & 1.033787 & -1.02 & 0.311 & -3.095275 & .9911996 \\
\hline Gov-Cons & $2.01 \mathrm{e}-07$ & $2.92 \mathrm{e}-08$ & 6.88 & 0.000 & $1.43 \mathrm{e}-07$ & $2.58 \mathrm{e}-07$ \\
\hline Labor & -.0000378 & $6.92 \mathrm{e}-06$ & -5.46 & 0.000 & -.00000514 & -.0000241 \\
\hline Tradeop & $1.39 \mathrm{e}-08$ & $3.22 \mathrm{e}-09$ & 4.32 & 0.000 & $7.55 \mathrm{e}-09$ & $2.03 \mathrm{e}-08$ \\
\hline Growth & -2.295589 & 2.128515 & -1.08 & 0.283 & -6.502514 & 1.911335 \\
\hline -cons & 308.7907 & 27.48065 & 11.24 & 0.000 & 254.4763 & 363.1051 \\
\hline
\end{tabular}

Number of obs $=154$

$\mathrm{F}(8,145)=157.92$

Prob $>\mathrm{F}=0.000$

R-squared $=0.8970$

Adj R-squared $=0.8914$

According the results of Table 2, the coefficient of determination, $\mathrm{R}^{2}$ has a high value which is $87,14 \%$, it indicates that $87,14 \%$ of the variance in GDP can be explained by fdi, gdp, gfcf, $\mathrm{k}$, inflation, government consumption, labour, trade-openess and growth rate. However, the good fit is most likely due to a highly linear relationship between GDP and the other variables.

The coefficient estimate for fdi is significant because the p-value is less than 0.05 . This means the coefficient estimate indicates that if fdi increases by one US dollar, GDP will increase by $-1.84 \mathrm{e}-07$ US dollar, ceteris paribus. Furthermore, Table 2 shows that the coefficient estimates for the independent variable of interest. The P-value of gfcf is $(0.000)$ is less than $5 \%$ that's means is significant, tradeopeness $(0.000)$ the P-value is less than $5 \%$ so it significant if tradeopeness increase by one US dollar, GDP will increase by 1.958178 . The p-value of inflation (0.311), capital (0.072) and growth (0.283) are more than $5 \%$ so these variables are not significant to the dependent variable GDP. According to our results the variables (FDI, GFCF, Gov, Trad and Lab) all are significant and influence the GDP variable; so these variables are meaningful and have an impact on FDI. These variables have a positive impact on economic growth, if they increase by one unit, GDP will increase by one unit and the expectation for exchange rate and political instability will be satisfied.

Our result for our simple regression will help us to analyze the random effect test.

This regression in Table 3 is the regression with fixed effects of the dependent variable GDP on independent variable's FDI, GFCF, K, Inflation, Gov-Cons, Labor, Trad-Open and Growth. 
Table 3. Fixed effect model

\begin{tabular}{cllllll}
\hline GDP & \multicolumn{1}{c}{ Coef } & \multicolumn{1}{c}{ Std.err } & \multicolumn{1}{c}{$\mathbf{T}$} & \multicolumn{1}{c}{$\mathbf{P}>/ \mathbf{t} /$} & \multicolumn{1}{|c|}{$\mathbf{9 5 \%}$ conf } & \multicolumn{1}{c}{ Interval] } \\
\hline FDI & $-8.57 \mathrm{e}-08$ & $3.20 \mathrm{e}-08$ & -2.68 & 0.008 & $-1.49 \mathrm{e}-07$ & $-2.25 \mathrm{e}-08$ \\
\hline GFCF & $1.86 \mathrm{e}-07$ & $2.95 \mathrm{e}-08$ & 6.30 & 0.000 & $1.27 \mathrm{e}-07$ & $2.44 \mathrm{e}-07$ \\
\hline K & $-3.97 \mathrm{e}-08$ & $2.26 \mathrm{e}-08$ & -1.75 & 0.081 & $-8.44 \mathrm{e}-08$ & $5.02 \mathrm{e}-09$ \\
\hline Inflation & -1.875519 & .5898606 & -3.18 & 0.002 & -3.041779 & -.70926 \\
\hline Gov-Cons & $2.24 \mathrm{e}-07$ & $2.24 \mathrm{e}-07$ & 11.09 & 0.000 & $1.84 \mathrm{e}-07$ & $2.63 \mathrm{e}-07$ \\
\hline Labor & -.0000254 & -.0000254 & -2.64 & 0.009 & -.0000445 & $-6.39 \mathrm{e}-06$ \\
\hline Tradeop & $1.03 \mathrm{e}-08$ & $1.03 \mathrm{e}-08$ & 2.82 & 0.005 & $3.08 \mathrm{e}-09$ & $1.75 \mathrm{e}-08$ \\
\hline Growth & -1.076845 & -1.076845 & -0.89 & 0.375 & -3.471449 & 1.31776 \\
\hline -cons & 285.2588 & 285.2588 & 9.29 & 0.000 & 224.5701 & 345.9474 \\
\hline
\end{tabular}

Prob $>\mathrm{F}=0.000$

R-squared $=0.9076$

Adj R-squared $=0.8914$

According to our result for fixed effect, the estimated value of $\mathrm{R}^{2}$ is 0.9076 . We can say the Null Hypothesis in Random effect is appropriated and the Alternative hypothesis in fixed effect is appropriated.

The p-value is 0.000 so it is less than $5 \%$, we can reject null hypothesis and accept the alternative hypothesis. Fdi variable has (0.008), GFCF(0.000), inflation (0.002), government consumption (0.000), labor (0.009) and trade openness $(0.005)$ for these variables their p-value are less than $5 \%$ showing that regime has the positive effect on economic growth but very marginally and we can reject the null hypothesis and accept the alternative hypothesis. Our variable capital $(0.081)$ and growth $(0.375)$ these variables their p-value are more than $5 \%$, mean they aren't significant to the dependant variable GDP.

Table 4. Haussmann Test

Ho: Random effect is appropriate

H1: Fixed effect is appropriate

Failure of Haussmann test

Test for fixed effect

\section{Haussmann Test}

Note: The rank of the differenced variance matrix (2) does not equal the number of coefficient being tested (8), be sure this is what you expect, or there may be problems computing the test. Examine the output of your estimators for anything unexpected and possibly consider scaling your variables so that the coefficients are on similar scale.

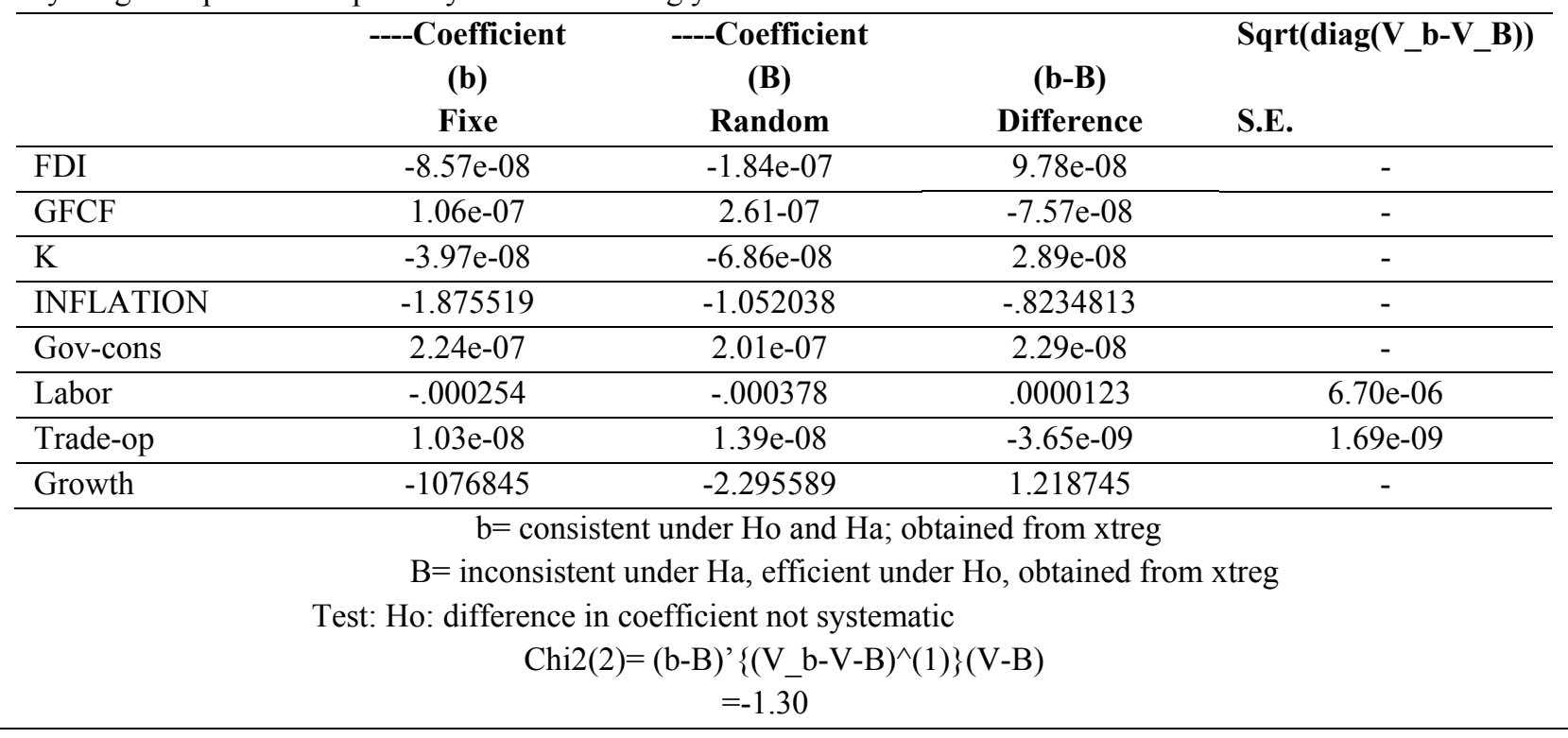


According to our results of Haussmann test, the p-value is less than 5\% so we can reject the null hypothesis and accept the alternative hypothesis that's means fixed effect model is appropriated. We can also say Haussmann test has shown us the fixed effect model is more appropriated and is the best model that represents our model.

Table 5. Breusch Pagan test

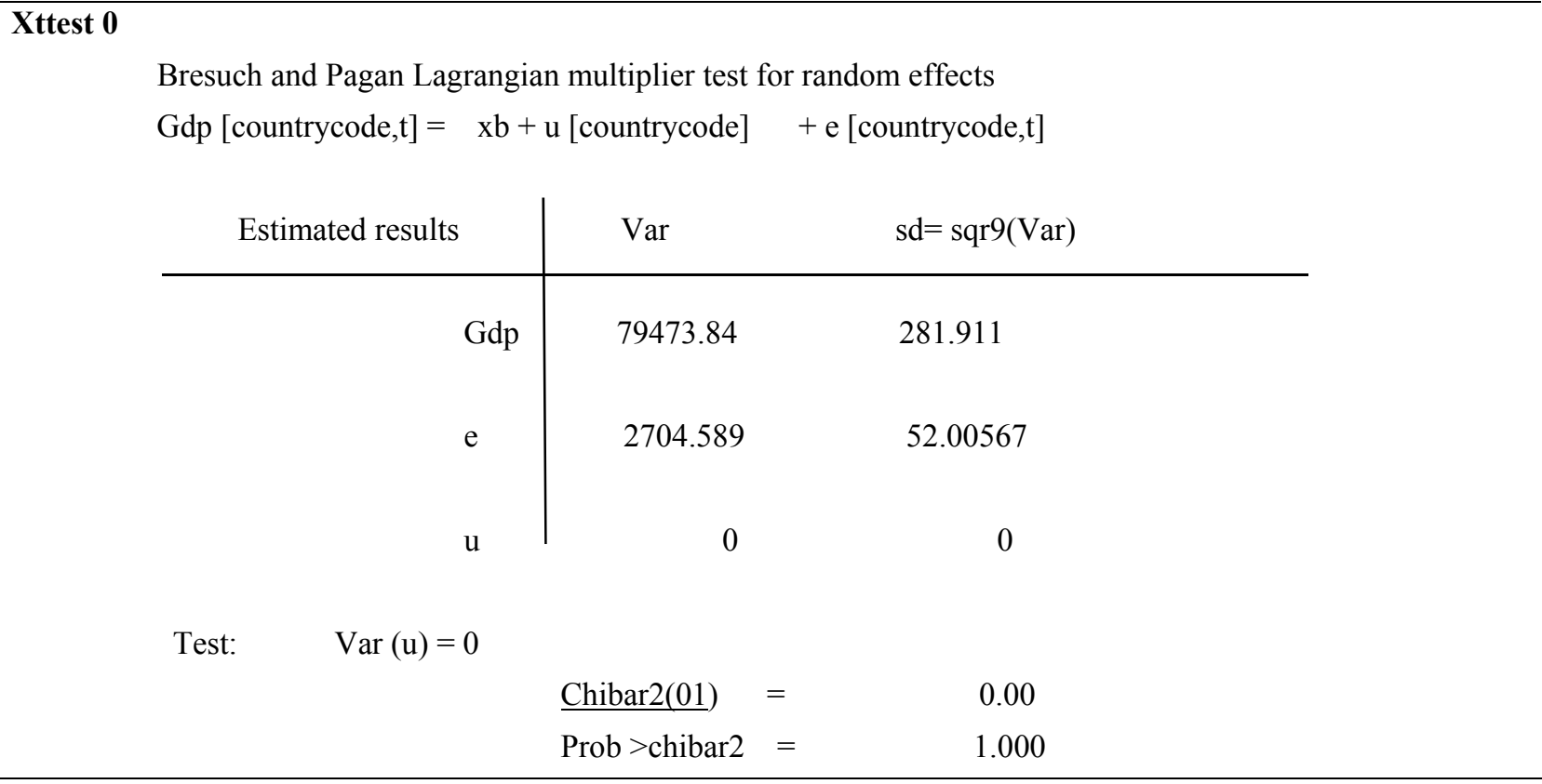

Ho: Null Hypothesis: Pooled regression is appropriated

H1: Alternative Hypothesis: Random effect is appropriated

We have for our Breush Pagan test H0: Null Hypothesis and H1: Alternative Hypothesis:

According to the result of Breusch Pagan test, P value is 0.000, that's mean is less than 5\%, so we can reject the null hypothesis and accept the alternative Hypothesis. The analysis for breusch Pagan test showed that FDI is affecting GDP significantly gross fixe capital formation, inflation, government consumption, labour and trade openness. So that's means we are satisfied with our model. Our all test Haussmann and Breusch pagan test are both telling random effect is the best model to represent our model.

\section{Conclusion}

The economic and econometric interpretation was made in a comprehensive manner, thus revealing generally satisfying results from the estimates of the model test and error correction, in order to explain the influence of certain variables on economic growth in WAEMU countries, for the period from1990 to 2012 were used. Specific variables for FDI, gross fixe capital formation, government consumption, labor and trade openness are significant for explaining their impact on economic growth.

Our paper was analysing the impact of Foreign Direct investment (FDI) on economic growth in WAEMU countries, our paper has explained the impact of FDI on economic growth in WAEMU countries within a well-defined methodological framework. Our results for the seven (7) developing countries of WAEMU show that FDI has a positive impact on economic growth in WAEMU. There is a strong, positive relationship between FDI and economic growth. FDI is often the main channel through which advanced technology is transferred to developing countries.

The tests we have done in our research showed that the variables FDI, gross fixed capital formation, government consumption, labor and trade openness are all significant at 5 these variables have an impact on economic growth and they are all significant. The amount of FDI increasing in WAEMU countries from U.S. \$ area - 2E + 08 million in 1992 to US \$ $1.1 \mathrm{E}+09$ million in 212 , representing nearly $60 \%$ increase. Our results of FDI trends showed that Niger is the largest recipient of FDI in WAEMU. It's followed by Mali then Ivory Coast, Burkina Faso and Senegal. We can say that the model is also globally significant. So the model is acceptable and we can be utilized for forecasting. 
Due to many socio-economic problems facing WAEMU countries, most have become desperate in trying to find solutions. The problems vary from high unemployment rates, poverty, and lack of technology. In their efforts to overcome these problems, most WAEMU countries have taken advice from bodies such as the IMF and the World Bank to liberalize their economies in order to attract FDI which in turn, they believe, will bring development.

The liberalization of economies have led to WAEMU countries engaging in privatization, introducing incentives to attract FDI in the form of tax holidays, relaxing regulatory framework, and introducing investment promotion agencies responsible for attracting FDI. Since most of the WAEMU countries have liberalized their economies, it would be expected that FDI flow to WAEMU countries, would have risen, but to the contrary; actual flows of FDI to Africa have been on the decline.

The privatization process, which has been preached by the IMF and the World Bank as one of the prerequisites for attracting FDI to developing countries was not successful and often resulted in further hardships for the poor as was the case in Zambia and many other African countries.

One of the main outcomes of using incentives to attract FDI is the increase of competition among WAEMU countries. This has led to countries engaging in a 'race to the bottom', offering investors more and more attractive financial incentives, and reducing the regulatory requirements on firms. Engaging in this type of competition almost inevitably means that even the country that 'wins' (the investment) has paid too high a price for it. Competition on investment incentives raises the distinct possibility that every country - big or small - could be worse off than if it were to refrain from using FDI incentives altogether.

WAEMU countries should exercise caution when they open their doors to FDI. In the process of attracting FDI, government should assess what kind of development the country needs, target FDI accordingly, and then set up policies which will guide the developmental process of the country. FDI must only be allowed to operate under certain nationally determined conditions and must conform to certain performance requirements that will ensure a positive impact on development and economic growth.

\section{References}

Andrew Mold. (2002). Foreign Direct Investment in Africa - Some Case Studies. IMF, Working Paper no. 0261, P 40.

Andrew Mold. (2002). Trade and Regional Integration Division United Nations Economic commission for Africa Addis Ababa, Ethiopia.

Balasubramanyam, V. N., Mohammed Salisu \& Dabid Sapsford. (1996, January). Foreign Direct Investment and Growth in EP and IS countries. Economic Journal, 106(434), 92-105.

Blomström, M., Fors, G., \& Lipsey, R. E. (1997). Foreign Direct Investment and Employment: Home Country Experience in the United States and Sweden. Economic Journal, 107.

Borensztein, E. J., De Gregorio, J., \& Lee, J. W. (1998). How Does Foreign Direct Investment Affect Economic Growth. Journal of International Economics, 45(1), 115-135.

De Mello, L. Jr. (1999, January). Foreign Direct Investment-Led Growth: Evidence from Time Series and Panel Data. Oxford Economic Papers, 51(1).

Dunning, J. H. (1973). The determinant of international production. Oxford Economic Papers, 25, 289-336.

Dunning, J. H. (1988). The Eclectic Paradigm of International Production: A Restatement and Some Possible Extensions. Journal of International Business Studies, 19(1), 1-31.

Dunning, J. H. (2000). The Eclectic Paradigm as an Envelope for Economic and Business Theories of MNE Activity. International Business Review, 9(1), 163-90.

Dunning, J. H., \& Rugman, A. M. (1985). The Influence of Hymer's Dissertation on the Theory of Direct Investment. The American Economic Review, 75(2), 228-232.

Grabowski, R., \& Shields, M. (1996). Development Economics. Oxford: Blackwell Publishers Ltd.

Greene, W. H. (1997). Econometrics Analysis (3rd ed.). Prentice Hall, Chapter 14.

International Monetary Fund. (1985). Foreign private investment in developing countries. A study by the international monetary fund research Department Occasional paper No 33.

M. Dembele Alassane Makan. (2008, August). Impact of FDI on economic growth in Ivory Coast, pp 46-47. 
Mansouri, B. (2004, June). Impact of Drought and Fiscal Policy on Private Consumption, Private Investment and Economic Growth in Morocco: An Empirical Analysis. Paper presented for Workshop on 'The Prospects of Arab Economic Cooperation to Boost Savings and Investment', Alexandria, Egypt, 22-24.

Nair-Reichert, Usha, \& Weinhold, Diana. (2001). Causality tests for cross-country panels: a new look at FDI and economic growth in developing countries. Oxford Bulletin of Economics and Statistics, 63(2), 153-171.

Narayan Sethi. (2004). Effect of FDI on Economic Growth in Bangladesh and India: An Empirical Investigation. India, Central University of Jharkhand, pp. 25-28.

Obadan, M. I. (2004). Globalization and Economic Management in Africa. Globalization and Africa's Economic Development. Ibadan: Nigerian Economic Society, pp. 3-34.

Sayek, S. (2000). Foreign Direct Investment and Inflation: Theory and Evidence. Unpublished manuscript.

Schneider, F., \& Frey, B. (1985). Economic and political determinants of foreign direct investment. World Development, 13, 161-175.

Solow, R. M. (1957). Technical Change and the Aggregate Production. Review of Economics and Statistics, 39, 312-320.

Thomas Layton, B. S. (2011). The Effects of Sectoral Components of GDP on FDI Inflows in Developing Countries. Texas Tech University, USA May, 33-34.

UNCTAD. (1999). Foreign Direct Investment and Development. UNCTAD Series on Issues in International Investment Agreements. New York and Geneva: United Nations.

United Nations Conference on Trade and Development. (1999). Foreign Direct Investment in Africa: Performance and Potential. New York and Geneva: United Nations.

Vasileios Chartas. (2005). The impact of Foreign Direct Investment on Economic growth in China. Eramus School Rotterdan, Netherland, pp13-18.

W.T.O. (2010). Niger Trade Brief. World Trade Indicators, 2009/10, pp. 01-02.

World Bank. (1987). World Development Report 1987. Washington DC, USA.

World Bank. (1996). World Debt Tables: External Finance for Developing Countries, Vol. 1 (Analysis and Summary Tables). Washington, D.C.: The World Bank.

Zhang, K., \& Markusen, J. (1999). Vertical multinational enterprises in Malaysia. Geneva: International Labour office.

Zhang, Q., \& Felmingham, B. (2001). The relationship between inward direct foreign investment and China's provincial export trade. China Economic Review, 12(2001), 82-99. 